\title{
TANGGUNG JAWAB PEMILIK KAPAL DALAM PERJANJIAN CARTER KAPAL BERDASARKAN WAKTU DI PT BUANA JAYA PRATAMA (STUDI KASUS PUTUSAN PENGADILAN TINGGI NOMOR: 745/PDT/2016/PT.DKI.)
}

\author{
Kenny Jusup \\ (Mahasiswa Program S1 Fakultas Hukum Universitas Tarumanagara) \\ (E-mail: kennyjusup@yahoo.com)
}

\section{Hanafi Tanawijaya}

(Corresponding Author)

(Dosen Hukum Agraria Fakultas Hukum Universitas Tarumanagara, Meraih Gelar Sarjana dari

Fakultas Hukum Universitas Tarumanagara, Magister Hukum Dari Fakultas Hukum Universitas

Tarumanagara)

(E-mail: Hanafitanawijaya@gmail.com)

\begin{abstract}
Any activity undertaken by a person in order to fulfill his or her life needs will surely relate and use the treaty law. However, both in the manufacture and implementation of the agreement, did not rule out other human possibilities. therefore, a legal norm is required so that in the process of interpersonal life there is peace and order. The interesting problem to be raised in this thesis is about the misconduct done by PT Haluan Segara Line to PT Buana Jaya pratama. In such cases, there is a contractual relationship between PT Buana Jaya Pratama and PT Haluan Segara Line during the charter lease charter agreement there is a rule to comply with all rules contained in the agreement. So that where the time of the agreement has expired, PT Haluan Segara Line does not want to pay the vessel on the ground that PT Haluan Segara Line does not make an agreement on the lease of the vessel, there was an act of default.

Keywords: treaty law, charter, contractual relationship
\end{abstract}




\section{PENDAHULUAN}

\section{A. Latar Belakang}

Saat ini, industri penyewaan kapal laut semakin berkembang di Indonesia. Hal ini disebabkan mahalnya harga sebuah kapal laut, sehingga banyak pengusaha pengangkutan yang cenderung memilih mencarter kapal laut (tongkang) daripada membeli untuk mempergunakan kapal laut tersebut dalam waktu yang tidak rutin untuk keperluan pengangkutan barang dari satu tempat ke tempat lain. Mahalnya biaya perawatan kapal laut pun menjadi salah satu alasan mengapa industri pencarteran kapal laut semakin berkembang di Indonesia. Untuk merawat sebuah kapal laut saja memerlukan biaya puluhan juta bahkan ratusan juta rupiah.

Manfaat dari transportasi laut adalah untuk distribusi barang, menghemat tenaga, dapat menjangkau daerah yang sebagian besar adalah perairan, mengangkut orangorang menyebrang ke pulau lain, dan untuk pertukaran informasi. Dalam kegiatan sewa menyewa transportasi laut terlebih dahulu mengadakan suatu perjanjian antara pihak satu dengan pihak yang lainnya. Perjanjian pengangkutan adalah suatu perjanjian antara pengangkutan dengan suatu pihak kedua (penumpang, pemilik barang, pengirim barang ataupun penerima barang). Dalam perjanjian ini pengangkut mengikatkan diri untuk mengangkut orang atau barang ke suatu tempat dengan selamat, dan pengangkut akan memperoleh imbalan dari pihak kedua berupa upah pengangkutan. Sifat dasar dari perjanjian pengangkutan merupakan perjanjian campuran (jasa dan pemborongan), timbal balik para pihak mempunyai kewajiban untuk melakukan dan berhak memperoleh prestasi dan konsensual perjanjian pengangkutan sah terjadinya kesepakatan

Kegiatan penyelenggaraan pengangkutan laut dapat dilakukan sendiri oleh pemilik kapal atau bisa dilakukan oleh pencarter kapal yang telah melakukan perjanjian pencarteran kapal. Pemilik kapal (ship owner) dapat mencarterkan kapal yang dimiliki kepada pencarter kapal (charterer) dengan berbagai ketentuan yang dicantumkan dalam bentuk perjanjian carter kapal (charter party). 
Dikarenakan hubungan yang timbul antara pemilik kapal dengan calon pemakai jasa adalah hubungan perikatan berdasarkan perjanjian maka penulis dapat bertumpu pada Pasal 1313 Kitab Undang-Undang Hukum Perdata adalah: “ Perjanjian adalah suatu perbuatan dengan mana satu pihak atau lebih mengikatkan dirinya terhadap satu orang atau lebih “. 1) Sedangkan menurut R. Subekti perjanjian itu adalah suatu peristiwa dimana seorang berjanji kepada orang lain atau dimana dua orang saling berjanji untuk melaksanakan suatu hal. ${ }^{2)}$

Perjanjian carter perjalanan merupakan perjanjian carter kapal dalam bentuk formal dan tertulis yang memperjanjikan kapal untuk melakukan hanya satu perjalanan beserta ketentuan-ketentuan lain bagi para pihak dalam perjanjian. Perjanjian carter waktu pada dasarnya sama merupakan bentuk formal tertulis, namun dibuat untuk penggunaan kapal pada waktu tertentu, sedangkan perjanjian demise/bareboat merupakan perjanjian untuk penggunaan kapal saja.

Proporsal Skripsi ini membahas tentang Tanggung Jawab Pengangkutan Barang Dalam Perjanjian Carter Kapal Berdasarkan Waktu yaitu bermula kasus PT Buana Jaya Pratama yang menggugat PT Pelayaran Haluan Segara Line selaku Tergugat I dan PT Nett Samudera Logistics selaku Tergugat II atas tindakan wanprestasi terhadap perjanjian sewa menyewa. Bermula dari PT Buana Jaya Pratama sebagai penggugat melakukan Perjanjian Sewa Menyewa Tugboat and Barge No: BJP/034/PHSL/VII/2015 tanggal 6 Juli 2015 yang isinya adalah untuk menyewakan kapal tugboat TB Mega Three / Barge APOL 3016 yang telah disepakati oleh para pihak. Perjanjian tersebut dibuat mulai pada tanggal 7 Agustus 2015 telah terjadi penggunaan jasa sewa menyewa kapal tugboat TB Mega Three / Barge APOL 3016; Atas Kesepakatan dalam kedua Perjanjian Sewa Menyewa dimaksud maka telah disetujui oleh para pihak harga sewa kapal sebesar Rp. 550.000.000 (lima ratus lima

\footnotetext{
${ }^{1)}$ Subekti dan Tjitrosudibio, Kitab Undang-Undang Hukum Perdata, (Jakarta: Pradnya Paramita, 2001), hal. 338.

2) R. Subekti, Hukum Perjanjian, (Jakarta: PT Intermasa, 2005), hal.1.
} 
puluh juta rupiah) di luar PPN perbulan dan apabila ke wilayah Sorong harga sewa kapal menjadi sebesar Rp. 600.000 .000 (enam ratus juta rupiah).

Penggugat dalam gugatannya mengatakan bahwa PT Pelayaran Haluan Segara Line selaku Tergugat I hanya dipinjam namanya saja dikarenakan ada kebijakan pengurangan PPN 10\% untuk PT yang sudah mempuyai izin pengangkutan laut / SIUPAL. Sedangkan PT Nett Samudera Logistics selaku penjamin telah melakukan tindakan wanprestasi terhadap perjanjian sewa menyewa tersebut yaitu tidak membayar sewa lalu kabur. Tetapi gugatan dari penggugat PT Buana Jaya Pratama tidak dapat diterima oleh Pengadilan Negeri Jakarta Pusat karena dianggap gugatan tersebut prematur. Bertitik tolak dari uraian tersebut, maka penulis ingin meneliti lebih lanjut mengenai permasalahan yang berjudul "Tanggung Jawab Pemilik Kapal Dalam Perjanjian Carter Kapal Berdasarkan Waktu di PT Buana Jaya Pratama (Studi Putusan Pengadilan Tinggi Nomor: 745/PDT/2016/PT.DKI.)”.

\section{B. Permasalahan}

Berdasarkan uraian tersebut di atas, maka penulis mempunyai suatu masalah yaitu bagaimanakah tanggung jawab pemilik kapal dalam perjanjian carter kapal berdasarkan waktu pada perusahaan pelayaran PT Buana Jaya Pratama sesuai dengan ketentuan yang berlaku?

\section{Metode Penelitian}

Metode penelitian hukum adalah metode yang digunakan dalam suatu proses untuk menemukan aturan hukum, dan prinsip-prinsip hukum, dalam menyelesaikan masalah yang dihadapi. ${ }^{3}$

1. Tipe Penelitian

Metode penelitian yang digunakan oleh penulis dalam penelitian ini adalah metode penelitian hukum normatif. Penelitian hukum normatif adalah

\footnotetext{
${ }^{3}$ Peter Mahmud Marzuki, Penelitian Hukum. (Jakarta: Kencana Media Group, 2006), hal. 35.
} 
penelitian hukum yang dikonsepkan sebagai pranata sosial yang secaara rill dikaitkan dengan variabel-variabel sosial yang lain. Sumber Penelitian

Dalam penelitian ini, peneliti menggunakan bahan-bahan hukum sebagai berikut :

1) Bahan Hukum Primer

Yaitu, data yang berupa bahan hukum, dan berasal dari aturan yang mengikat, seperti Kitab Undang-Undang Hukum Perdata buku ketiga tentang perikatan, Kitab Undang-Undang Hukum Dagang buku kedua tentang hak-hak dan kewajiban-kewajiban yang timbul dari pelayaran, dan Putusan Pengadilan Tinggi Nomor: 745/PDT/2016/PT.DKI tentang tanggung jawab pemilik kapal dalam perjanjian carter kapal berdasarkan waktu di PT Buana Jaya Pratama.

2) Bahan Hukum Sekunder

Yaitu termasuk didalamnya buku-buku skripsi, tesis, disertasi hukum, dan jurnal hukum. Dalam penelitian ini penelusuran bahan hukum sekunder terdiri dari penelusuran literatur-literatur, buku-buku, jurnal, skripsi, tesis, dan disertasi yang terkait dengan Kebijakan Hukum Perdata yang membahas mengenai wanprestasi dan perikatan suatu perjanjian.

3) Bahan Non-Hukum

Yaitu bahan-bahan penunjang di luar bahan hukum primer maupun sekunder sebagai bahan pelengkap bukan yang utama serta memberikan petunjuk tambahan terhadap bahan-bahan hukum tersebut yaitu berupa Kamus Besar Bahasa Indonesia (KBBI), Kamus Bahasa Belanda-Indonesia.

\section{Pendekatan}

Dalam penelitian hukum juga terdapat beberapa pendekatan. Dengan pendekatan tersebut, peneliti akan mendapatkan informasi dari berbagai 
aspek mengenai isu yang sedang dicoba untuk dicari jawabannya. Macammacam pendekatan-pendekatan yang digunakan di dalam penelitian hukum adalah: ${ }^{4}$

1. Pendekatan undang-undang (statute approach)

2. Pendekatan kasus (case approach)

3. Pendekatan historis (historical approach)

4. Pendekatan komparatif (comparative approach)

5. Pendekatan konseptual (conceptual approach)

Penelitian yang dilakukan oleh penulis lebih ditujukan kepada pendekatan undang-undang dan pendekatan kasus. Pendekatan undangundang dilakukan dengan menelaah semua undang-undang dan regulasi yang bersangkut paut dengan isu hukum yang sedang ditangani ${ }^{5}$ dan pendekatan kasus dilakukan dengan cara melakukan telaah terhadap kasus-kasus yang berkaitan dengan isu yang dihadapi yang telah menjadi putusan pengadilan yang telah mempunyai kekuatan yang tetap. ${ }^{6}$

\section{Teknik Pengumpulan Bahan Hukum}

Penulis menggunakan teknik pengumpulan bahan hukum dengan tinjauan pustaka (library research) dari bahan sekunder yang berasal dari artikelartikel di internet, buku-buku dan literatur lainnya.

4. Teknik Pengelolaan Bahan Hukum

Penulis menggunakan teknik pengelolaan bahan hukum yang runtut dan sistematis sehingga memudahkan penulis melakukan analisis. Pengelolaan bahan hukum dilakukan secara sistematis bertujuan untuk mendapatkan gambaran umum dari hasil penelitian.

5. Teknik Analisis Bahan Hukum

\footnotetext{
${ }^{4}$ Peter Mahmud Marzuki, Penelitian Hukum, (Jakarta : Kencana Prenada Media Group, 2009), hal. 93.

5 Ibid., hal. 93.

${ }^{6}$ Ibid., hal. 94.
} 


\begin{abstract}
Penulis menggunakan teknik analisis bahan hukum kualitiatif, yaitu penelitian yang menekankan pada bahan-bahan hukum yang diperoleh dari berbagai sumber, seperti buku-buku, artikel, jurnal, serta peraturan perundang-undangan yang terkait.
\end{abstract}

\title{
II. PEMBAHASAN
}

\section{A. Hasil Penelitian}

PT Buana Jaya Pratama yaitu suatu perseroan terbatas yang didirikan berdasarkan hukum Republik Indonesia, berkedudukan di APOL, Jalan Abdul Muis No.40, Petojo Selatan, Gambir, Jakarta Pusat 10160, dalam hal ini diwakili oleh Alexander Runtuwene dan Ferdy Suwandi masing-masing dalam kedudukannya selaku Direktur Utama dan Direktur oleh karenanya sah bertindak untuk dan atas nama perseroang tersebut (untuk selanjutnya disebut "Pemilik Kapal") dan PT Pelayaran Haluan Segara Line yaitu suatu perseroan terbatas yang didirikan berdasarkan hukum Republik Indonesia, berkedudukan di Kebon Bawang IV No.23, Kelurahan Kebon Bawang, Kecamatan Tanjung Priok, Jakarta Utara, dalam hal ini diwakili oleh Zulfan Siregar selaku Direktor Utama, oleh karenanya sah bertindak untuk dan atas nama perseroan tersebut (untuk selanjutnya disebut "Penyewa")

Perjanjian sewa-menyewa kedua belah pihak ini terjadi pada hari Senin tanggal 6 juli 2015 PT Buana Jaya Pratama selaku pemilik kapal setuju untuk menyewakan kepada PT Pelayaran Haluan Segara Line selaku penyewa berupa 1 (satu) kapal berupa tugboat TB Buleleng dan Barge APOL 3017 atau penggantinya beserta para Anak Buah Kapal (ABK)/crew dengan spesifikasi teknis Kapal/Ship Particular, (untuk selanjutnya disebut "Kapal").

Pemilik Kapal menyerahkan Kapal (delivery) beserta dokumen-dokumennya kepada Penyewa di wilayah sekitar Pelabuhan Merak/Jakarta atau tempat yang disetujui Pemilik Kapal (selanjutnya disebut sebagai “Tempat Delivery") dengan estimasi kedatangan laycan pada hari Selasa tanggal 7 Juli 2015 sampai dengan hari 
Jumat tanggal 10 Juli 2015. Pemilik Kapal yang diwakili oleh nahkoda Kapal akan menyiapkan Berita Acara Serah Terima Kapal ("BASTK") yang berisi antara lain tanggal on hire Kapal serta informasi persediaan bahan bakar (bunker) dan air tawar serta jumlah awak Kapal yang berlayar. Setelah melakukan pengecekan, Penyewa akan menyetujui dan menandatangani BASTK tersebut.

Pemilik Kapal harus menginformasikan secara tertulis kepada Penyewa mengenai waktu on hire survey selambat-lambatnya 3 (tiga) hari kalender sebelum Kapal di survey. On hire survey dilakukan segera setelah Kapal tiba dan Kapal harus dalam keadaan siap untuk di-survey, baik pada hari Minggu atau hari libur nasional/internasional.

Penyewa menyerahkan kembali Kapal (re-delivery) beserta dokumendokumennya kepada Pemilik Kapal di wilayah sekitar pelabuhan Banjarmasin atau di tempat yang disetujui oleh Pemilik Kapal (selanjutnya disebut sebagai "Tempat $R e$ delivery") pada tanggal yang sesuai dengan akhir periode masa sewa dan Para Pihak akan menyiapkan Berita Acara off hire yang berisi antara lain tanggal dan tempat off hire Kapal, informasi persediaan bahan bakar (bunker) dan informasi lainnya yang dibutuhkan yang kemudian ditandatangani oleh Para Pihak atau wakilnya.

Off hire survey dilakukan oleh Penyewa dan disetujui oleh Pemilik Kapal, Penyewa harus menginformasikan secara tertulis kepada Pemilik Kapal mengenai waktu off hire survey selambat-lambatnya 3 (tiga) hari kalender sebelum Kapal disurvey off hire survey dilakukan segera setelah Kapal tiba di Tempat Re-delivery atau ditempat yang disetujui oleh Pemilik Kapal dan dalam keadaan siap untuk di-survey, baik pada hari Minggu atau hari libur nasional/internasional. Apabila tangal periode sewa terlewati oleh karena Penyewa harus melengkapi satu voyage-nya, maka biaya atas kelebihan waktu tersebut akan diperhitungkan secara pro-rata.

Apabila hasil off hire survey menyatakan adanya peralatan/bagian/dokumen Kapal yang rusak/hilang oleh karena kesalahan pihak Penyewa, maka Penyewa wajib 
memperbaiki/mengganti peralatan/bagian/dokumen Kapal tersebut dan segala waktu dan biaya yang terjadi akan menjadi beban Penyewa.

Bahan bakar (bunker) yang terdapat di Kapal pada saat on hire diambil alih oleh Penyewa dan pada saat off hire, Pemilik Kapal mengambil alih sejumlah bahan bakar (bunker) yang tersisa di Kapal. Apabila ada kekurangan kuantitas bahan bakar (bunker) pada saat off hire disbanding kuantitas pada saat on hire, maka Penyewa harus membayarkan selisih harga bahan bakar (bunker) berdasarkan harga pasaran bahan bakar (bunker) pada saat itu dalam waktu 7 (tujuh) hari kalender.

Periode sewa menyewa Kapal disepakati selama 6 (enam) bulan sewa terhitung sejak tanggal BASTK ditandatangani dan dapat diperpanjang kembali sampai dengan 6 (enam) bulan berikutnya berdasarkan persetujuan dari Pemilik Kapal.

Penyewa dalam hal ingin memperpanjang kembali Perjanjian akan memberikan pemberitahuan tertulis kepada Penyewa paling lambat 1 (satu) minggu sebelum berakhirnya Perjanjian.

Dalam hal Penyewa melakukan off hire dan mengakhiri Perjanjian baik sebelum atau sesudah masa periode sewa berakhir sesuai dengan Perjanjian ini maka Penyewa wajib menyerahkan kembali Kapal (re-delivery) beserta dokumen-dokumennya kepada Pemilik Kapal sesuai dengan Perjanjian.

Pemilik Kapal menjamin kepada Penyewa bahwa Kapal tidak akan disewakan kepada pihak ke-tiga manapun oleh Pemilik Kapal selama periode sewa dengan Penyewa dan memberikan Penyewa hak eksklusif untuk mengoperasikan Kapal selama masa on hire Kapal berdasarkan Perjanjian ini tanpa adanya claim maupun campur tangan Pemilik Kapal maupun ke-tiga manapun, kecuali ditentukan lain berdasarkan kesepakatan Para Pihak.

Dengan berakhirnya Perjanjian, tidak mengurangi dan atau membebaskan hak dan kewajiban masing-masing Pihak yang telah timbul sebelum Perjanjian diakhiri sampai seluruh hak dan kewajiban tersebut dinyatakan selesai oleh Pihak lainnya. 
Penyewa akan mengoperasikan Kapal di seluruh wilayah perairan Indonesia kecuali di Indonesia wilayah bagian Timur, wilayah perairan Cilacap dan wilayah perairan Aceh.

Kapal tidak boleh diinstruksikan berlayar ke daerah yang dinyatakan sebagai zona berbahaya namun tidak terbatas pada wilayah perairan Negara yang sedang dalam keadaan perang, terdapat teroris, membahayakan Kapal secara teknis dan sebagainya, kecuali mendapat persetujuan tertulis sebelumnya dari Pemilik Kapal.

Kapal tidak boleh dioperasikan di daerah yang dangkal dan atau dimana pelabuhannya adalah tidak aman bagi kondisi Kapal dan awaknya yang menurut Pemilik Kapal membahayakan Kapal dan Kapal tidak diperbolehkan membawa dan/atau menarik tongkang dengan muatan barang-barang berbahaya dan atau illegal, semua jenis kayu, kargo kimia, dan barang lainnya yang dilarang dalam dokumen Kapal dan atau peraturan perundangan Indonesia dan atau regulasi internasional. Kapal hanya diperbolehkan untuk menarik muatan.

Para Pihak setuju bahwa harga sewa Kapal adalah sebesar IDR. 550.000.000,- per bulan di luar ppn 10\% dan pajak-pajak lain selain PPN 10\%, yaitu bea materai, iuran dan pungutan-pungutan lainnya yang timbul berkenaan dalam pelaksanaan Perjanjian ini dan sepenuhnya menjadi tanggungan Penyewa, kecuali PH menjadi tanggungan Pemilik Kapal.

Apabila salah satu Pihak melanggar kewajiban dan tanggung jawabnya masingmasing sebagaimana diatur dalam Perjanjian ini, maka Pihak lainnya berhak memberikan peringatan tertulis maupun lisan kepada Pihak yang melanggar tersebut dan apabila tidak dilakukan upaya pemulihan, maka Pihak yang lainnya berhak memutuskan Perjanjian secara sepihak, dengan persetujuan tertulis sebelumnya dari Pihak yang lain sesuai dengan yang diatur di dalam Perjanjian ini.

Di dalam Perjanjian ini terjadi suatu tindakan yang dilakukan Pemilik Kapal terhadap Penyewa Kapal yang dianggap telah melakukan "Wanprestasi" terhadap apa yang di perjanjikannya. Sehingga Pemilik Kapal menggugat Penyewa Kapal ke 
Pengadilan Jakarta Pusat. Awal mula terjadi suatu tindakan wanprestasi ketika tagihan yang sesuai dengan Perjanjian tersebut, pada kenyataannya Penyewa Kapal tidak melakukan kewajibannya untuk melakukan pembayaran kepada Pemilik Kapal sesuai dengan total biaya dimaksud, dengan demikian Penyewa Kapal telah lalai (wanprestasi) yang mana atas kelalaian Penyewa Kapal, Pemilik Kapal telah beberapa kali mencoba mengingatkan secara patut dan melakukan penagihan terhadap Penyewa Kapal untuk menyelesaikan pembayaran hutang tersebut baik secara lisan maupun tertulis dengan mengirimkan Surat Peringatan ke-1 (satu) tertanggal 24 Agustus 2015 kepada Penyewa Kapal. Ketika diberi jangka waktu untuk membayar kewajibannya kepada Penyewa Kapal, namun kenyataannya sampai dengan batas waktu yang diberikan pada Surat Peringatan tersebut, Penyewa Kapal belum juga melakukan Pembayaran kewajibannya ataupun merespon Surat Peringat tersebut, sehingga kembali dengan itikad baik, Pemilik Kapal mencoba kembali mengingatkan kepada Penyewa Kapal mengenai hutang dengan mengirimkan Surat Peringatan ke-2 (dua) tertanggal 25 September 2015 agar Penyewa Kapal segera melakukan pembayaran kewajibannya terhadap Pemilik Kapal. Namun pada kenyataannya sampai dengan tanggal surat gugatan ini didaftarkan ke Pengadilan Negeri Jakarta Pusat Penyewa Kapal belum juga melakukan pembayaran atas Perjanjian Sewa Menyewa yang dimaksud.

Bahwa dengan dikirimkannya Surat Peringatan tersebut maka Pemilik Kapal telah memenuhi syarat formil diajukannya gugatan sebagaimana diatur dalam Pasal 1243 KUHPer bahwa tuntutan atas wanprestasi hanya dapat dilakukan apabila si berutang telah diberi peringatan bahwa ia melalaikan kewajibannya, namun kemudian ia tetap melalaikannya.

\section{A. Putusan Pengadilan Negeri Nomor: 564/PDT.G/2015/PN/JKT/PST}

Tentang kedudukan perkara menimbang, bahwa Pembanding semula Penggugat dengan surat gugatannya tertanggal 30 November 2015, yang telah diterima dan didaftarkan di Kepaniteraan Pengadilan Negeri Jakarta Pusat pada tanggal 1 Desember 
2015 serta dicatat dalam Register Perkara Nomor 564/Pdt.G/2015/PN.Jkt.Pst., telah mengajukan gugatan yang pada intinya sebagai berikut:

Bahwa hubungan hukum yang timbul antara Penggugat dengan Tergugat terjadi akibat adanya Perjanjian sewa menyewa Tug and Barge Nomor BJP/035/PHSL/VII/2015 ("Perjanjian Sewa Menyewa") pada hari Senin, 6 Juli 2015 untuk menyewa kapal tugboat TB Buleleng/Barge APOL 3017 dan Perjanjian Sewa Menyewa Tug and Barge Nomor BJP/035/PHSL/VII/2015 untuk menyewa kapal tugboat TB Mega Three/Barge APOL 3016 yang telah disepakati oleh para pihak yaitu Penggugat sebagai pemilik kapal dan Tergugat sebagai penyewa;

Bahwa atas Perjanjian Sewa Menyewa tersebut, berdasarkan Berita Acara kapal On Hire / serah terima awal kapal tugboat TB.Buleleng/BG APOL 3017 tertanggal 10 juli 2015 telah membuktikan bahwa mulai pada tanggal 10 Juli 2015 telah terjadi penggunaan jasa sewa menyewa kapal tugboat TB Buleleng dan Barge APOL 3017 yang mana kapal tersebut adalah milik Penggugat sebagai perusahaan penyedia jasa perkapalan dengan Tergugat sebagai pengguna jasa/penyewa;

Bahwa selain perjanjian sewa menyewa kapal tugboat TB.Buleleng/BG APOL 3017 antara Penggugat dan Tergugat, pada kenyataannya Penggugat dan Tergugat telah ada kesepakatan untuk sewa menyewa Kapal tugboat TB Mega Three/Barge APOL 3016 yang mana berdsasarkan Berita Acara kapal On Hire/serah terima awal kapal tugboat TB Mega Three/Barge APOL 3016 tertanggal 7 Agustus 2015 telah membuktikan bahwa mulai pada tanggal 7 Agustus 2015 telah terjadi penggunaan jasa sewa menyewa kapal tugboat TB Mega Three/Barge APOL 3016;

Bahwa atas kesepakatan dalam kedua Perjanjian Sewa Menyewa dimaksud maka telah disetujui oleh para pihak harga sewa kapal sebesar Rp. 550.000.000 (Lima ratus lima puluh juta Rupiah) Diluar PPN perbulan dan apabila ke wilayah Sorong harga sewa kapal menjadi sebesar Rp. 600.000.000 (enam ratus juta Rupiah);

Dengan demikian total kewajiban Tergugat I berdasarkan Invoice No. INVN50000115 tertanggal 23 Juli 2015, Invoice No. INVN50000127 tertanggal 6 
Agustus 2015, Invoice No. BJP/FIN-250/VIII/2015 tertanggal 20 Agustus 2015, Invoice No. INVN50000128 tertanggal 6 Agustus 2015, Invoice No.BJP/FIN257/VIII/2015 tertanggal 26 Agustus 2015 adalah sebesar Rp.1.254.995.000 (Satu miliar dua ratus lima puluh empat juta Sembilan ratus Sembilan puluh lima ribu Rupiah);

Awal mula terjadi suatu tindakan wanprestasi ketika tagihan yang sesuai dengan Perjanjian tersebut, pada kenyataannya Tergugat I tidak melakukan kewajibannya untuk melakukan pembayaran kepada Penggugat sesuai dengan total biaya dimaksud, dengan demikian Tergugat I telah lalai (wanprestasi) yang mana atas kelalaian Tergugat I, Penggugat telah beberapa kali mencoba mengingatkan secara patut dan melakukan penagihan terhadap Tergugat I dan Tergugat II untuk menyelesaikan pembayaran hutang tersebut baik secara lisan maupun tertulis dengan mengirimkan Surat Peringatan ke-1 (satu) tertanggal 24 Agustus 2015 kepada Tergugat I dan juga Surat Peringatan ke-1 (satu) tertanggal 24 Agustus 2015 kepada Tergugat II yang bertindak sebagai penjamin atas kewajiban pembayaran yang dimiliki Tergugat I. Ketika diberi jangka waktu untuk membayar kewajibannya kepada Penggugat, namun kenyataannya sampai dengan batas waktu yang diberikan pada Surat Peringatan tersebut, Tergugat I Dan Tergugat II belum juga melakukan Pembayaran kewajibannya ataupun merespon Surat Peringat tersebut, sehingga kembali dengan itikad baik, Penggugat mencoba kembali mengingatkan kepada Penyewa Kapal mengenai hutang dengan mengirimkan Surat Peringatan ke-2 (dua) tertanggal 25 September 2015 agar Tergugat I segera melakukan pembayaran kewajibannya terhadap Penggugat. Namun pada kenyataannya sampai dengan tanggal surat gugatan ini didaftarkan ke Pengadilan Negeri Jakarta Pusat Penyewa Kapal belum juga melakukan pembayaran atas Perjanjian Sewa Menyewa yang dimaksud.

Dengan tidak dilaksanakannya kewajiban pembayaran oleh Tergugat berdasarkan Perjanjian Sewa Menyewa Tug and Barge Nomor BJP/035/PHSL/VII/2015 tertanggal 6 Juli 2015, maka Penggugat mengalami kerugian materiil sebesar Rp 
1.254.995.000,00 (satu miliar dua ratus lima puluh empat juta Sembilan ratus Sembilan puluh lima ribu rupiah); dan akibat dari perbuatan Tergugat dengan tidak memenuhi kewajiban pembayaran kepada Penggugat maka mengakibatkan kegiatan operasional dari Penggugat sangat terganggu dikarenakan harus keuangan (cash flow) dari Penggugat sangat bermasalah mengingat Penggugat adalah perusahaan penyedia jasa perkapalan dimana dalam menjalankan kegiatan bisnisnya kepada pelanggan/customer diperlukan modal/pengeluaran dimuka terlebih dahulu untuk biaya-biaya operasional seperti bahan bakar, gaji awak kapal dan sebagainya, sehingga akibat terganggunya arus keuangan (cash flow) tersebut maka Penggugat telah banyak kehilangan kesempatan mendapat pelanggan/customer dan oleh karenanya maka Penggugat telah mengalami kerugian immaterial sebesar Rp 10.000.000.000,00 (sepuluh miliar rupiah);

Pertimbangan Hakim Pengadilan Jakarta Pusat bahwa berdasarkan pertimbanganpertimbangan gugatan Penggugat bersifat prematur karena Penggugat setelah tidak dipenuhi kewajiban membayar uang sewa oleh Tergugat I, Penggugat belum mengajukan tuntutan pemenuhan kepada Tergugat II. Sehingga apabila penagihan telah dilakukan kepada Tergugat II dan ternyata Tergugat II tidak memenuhi "Pernyataan Jaminan" tersebut barulah cukup alasan bagi Pengguat untuk mengajukan gugatan kepada Tergugat II dengan dalil ingkar janji / wanprestasi;

Menimbang, bahwa pada petitum, Penggugat mohon agar Tergugat I dan Tergugat II dihukum untuk membayar secara tanggungrenteng atas kerugian materiil maupun immaterial yang diderita sebagai akibat tidak dipenuhinya kewajiban Tergugat I, tidak diuraikan secara terperinci alas an Tergugat I dan Tergugat II harus menanggung pembayaran secara tanggungrenteng. Pada sisi lain tuntutan tanggungrenteng bertentangan dengan sifat dari jaminan yang diberikan oleh Tergugat II;

Menimbang, bahwa berdasarkan pertimbangan di atas, gugatan Penggugat selain prematur, posita gugatan Penggugat yang diuraikan tidak sinkron dengan petitum yang 
dimohonkan. Dengan demikian cukup alasan gugatan Penggugat dinyatakan tidak dapat diterima;

Menimbang, bahwa karena gugatan dinyatakan tidak dapat diterima, maka kepada Penggugat akan dihukum untuk membayar segala biaya yang timbul dalam perkara ini.

\section{B. Putusan Pengadilan Tinggi Nomor: 745/PDT/2016/PT.DKI.}

Menimbang, bahwa setelah Majelis Hakim Tingkat Banding mempelajari memori banding sebagaimana yang telah diserahkan oleh Pembanding semula Penggugat, maka Majelis Hakim Tingkat Banding berpendapat bahwa terhadap alasan-alasan atau keberatan-keberatan dalam memori banding Pembanding semula Penggugat, sesungguhnya hanya merupakan pengulangan karena hal tersebut telah dipertimbangkan dalam putusan Majelis Hakim Tingkat Pertama dalam putusannya dengan pertimbangan dan dasar hukum yang cukup, karena itu keberatan Pembanding semula Penggugat dalam upaya hukum banding ini tidak beralasan;

Menimbang, bahwa demikian juga atas kontra memori banding yang diserahkan oleh Terbanding semula Tergugat segala ulasan dan permasalahan yang dikemukakan, oleh Majelis Hakim Tingkat Pertama telah dipertimbangkan dengan cermat dan berdasarkan penerapan hukum yang benar;

Menimbang, bahwa memperhatikan pertimbangan hukum Majelis Hakim Tingkat Pertama dalam putusan Pengadilan Negeri Jakarta Pusat Nomor 564/Pdt.G/PN.Jkt.Pst. tanggal 23 Agustus 2016, telah memuat dan menguraikan secara tepat dan benar, keadaan-keadaan serta alas an-alasan yang menjadi dasar hukum putusannya, sehingga oleh karenanya pertimbangan-pertimbangan tersebut dapat disetujui dan dipertahankan serta diambil alih dan dijadikan sebagai dasar pertimbangan Majelis Hakim Tingkat Banding;

Menimbang, bahwa berdasarkan alasan pertimbangan tersebut di atas, maka putusan Pengadilan Negeri Jakarta Pusat Nomor 564/Pdt.G/PN.Jkt.Pst. tanggal 23 Agustus 2016 yang dimohonkan banding tersebut harus dikuatkan. 


\section{Wawancara}

1. Wawancara dengan Ning Adiasih, SH, MH. Selaku Dosen Hukum Perdata dan Hukum Acara Perdata Fakultas Hukum Universitas Tarumanagara yang membahas tentang Perjanjian Sewa Menyewa.

Pertama-tama Sewa menyewa kapal di PT Buana Jaya Pratama meliputi 3 (tiga) tahap yaitu, Tahap persetujuan dimana antara pihak pemilik kapal dan penyewa (pencarter) melakukan kesepakatan kemudian setelah terpenuhinya kata sepakat dan persyaratan tekhnis serta administrasi lainnya maka dilanjutkan dengan tahap kedua yaitu Tahap pembuatan kontrak perjanjian/persetujuan dimana didalam surat kontrak sudah dimuat materi-materi spesifikasi lengkap mengenai nama perusahaan, kapal, muatan, besarnya harga sewa, dan lain-lain. Kemudian dilanjutkan dengan tahap ketiga yaitu Tahap Penataan Administrasi Persetujuan dimana masing-masing Pihak diminta untuk menandatangani surat kontrak/perjanjian yang sudah di siapkan barulan setelah itu penyewa kapal dapat memanfaatkan penggunaan kapal. Apabila salah satu pihak wanprestasi pihak PT Buana Jaya Pratama akan melakukan negoisasi secara arif dan bijaksana. Pihak penyewa harus bersedia membayar penalty/denda atau yang biasa disebut dengan demmurage perhari sesuai dengan kontrak yang telah disepakati oleh kedua belah pihak.

Dalam hal perjanjian ini berarti si penyewa harus taat kepada aturan yang diberlakukan di PT Buana Jaya Pratama dalam menyewa kapal, jika melanggar apa yang diberlakukan di PT Buana Jaya Pratama berarti penyewa telah melakukan tindakan wanprestasi. Dalam tindakan wanprestasi penyewa harus bersedia membayar penalty/denda yang tertulis pada perjanjian yang dilakukan antara PT Buana Jaya Pratama dengan si penyewa kapal. Karena didalam perjanjian memuat Asas bahwa semua perjanjian yang dibuat berlaku sebagai Undang-Undang bagi pihak yang membuat. Asas ini dikenal dengan istilah pacta sunt servanda. Asas ini mengandung pengertian bahwa perjanjian harus ditaati oleh 
pihak yang membuat perjanjian. Dan untuk si Penyewa pun ada ketentuan yang harus ditaati selaku pemilik kapal untuk merawat kapal dan melakukan perbaikan besar apabila kapal tersebut mengalami kerusakan sehingga memberikan si penyewa kenikmatan yang tenteram daripada barang yang disewakan selama berlangsungnya sewa. Jika kewajiban pihak yang menyewakan untuk memperbaiki kapal itu dilalaikan, maka si penyewa berdasarkan tidak dilaksanakannya perjanjian atau wanprestasi dapat menuntut ganti rugi bahwa pihak penyewa dapat melakukan sendiri perbaikan yang diperlukan itu, dan kemudian meminta ganti rugi dari biaya yang ia keluarkan untuk itu kepada pihak yang menyewakan.

Berdasarkan hasil wawancara antara penulis dengan Ibu Ning Adiasih selaku narasumber, penulis sepakat dengan apa yang dikatakan oleh Ibu Ning Adiasih terkait yang perlu dilakukan dan diperhatikan dalam Perjanjian Sewa Menyewa.

Akan tetapi penulis kurang sepakat mengenai apabila kapal yang mengalami kerusakan besar yang harus ditanggung oleh si pemilik kapal, ketika kerusakan besar terjadi disebabkan oleh si penyewa kapal maka si penyewa lah yang harus memperbaiki kapal tersebut tanpa meminta ganti rugi dari pemilik kapal.

2. Wawancara dengan Dr. Ahmad Sudiro, SH., MH., MM. selaku Dekan Fakultas Hukum Universitas Tarumanagara membahas tentang hal transportasi laut yang berfokus pada kapal.

Pertama-tama didalam perjanjian sewa menyewa kapal memuat materi sebagai berikut:

a. Nama dan alamat pemilik kapal sebagai pihak pertama, dan nama serta alamat penyewa kapal sebagai pihak kedua

b. Nama kapal beserta spesifikasinya, kecepatan, tonnase, bahan-bakar dan lainnya

c. Tempat dan waktu penyerahan kapal dan penyerahan kapal kembali dan tempat atau waktu pemuatan serta pembongkaran

d. Jenis barang yang sah yang akan diangkut

e. Pemakaian kapal oleh penyewa untuk tujuan yang sah 
f. Syarat-syarat pengangkutan dan tanggung jawab masing-masing pihak, g. Pembatasan lalu lintas dan pelabuhan-pelabuhan yang akan dimasuki

h. Besarnya harga sewa kapal dan syarat-syarat pembayaran.

Setelah surat kontrak sewa kapal selesai dibuat dan barang muatan siap diangkut ke dalam palka kapal, seterusnya barulah dilakukan tahap penataan administrasi dari persetujuan sewa yang sudah disepakati bersama.

Bapak Ahmad Sudiro mengatakan bahwa tidak semua pemilik kapal menulis isi perjanjian secara terperinci dan detail sehingga kadang dapat menimbulkan missed komunikasi antara penyewa dan pemilik kapal itu sendiri. Yang dapat menimbulkan kerugian bagi pihak penyewa dan pemilik kapal tersebut. Contohnya seperti ada kapal memiliki kerusakan yang tidak disadari oleh pemilik kapal sehingga dapat menimbulkan kerugian bagi penyewa kapal tersebut.

Berdasarkan hasil wawancara antara penulis dengan Bapak Ahmad Sudiro selaku narasumber, penulis sepakat dengan apa yang dikatakan oleh Bapak Ahmad Sudiro terkait yang perlu dilakukan dan diperhatikan materi dalam isi Perjanjian Sewa Menyewa Kapal tersebut secara detail dan terperinci sehingga tidak menimbulkan kerugian diakan datang antar kedua belah pihak. Karena mulai dari hal kecil seperti isi dari perjanjian tersebut dapat menimbulkan masalah yang besar ketika terjadi hal yang tidak diinginkan ketika dalam waktu menggunakan kapal tersebut.

\section{B. Analisa}

\section{Pengertian Tentang Pencarteran Kapal}

Pencarteran kapal adalah penggunaan/pengoperasian kapal milik orang lain, yang sudah diperlengkapi dengan alat perlengkapan kapal beserta pelautnya, yang siap untuk menjalankan kapal sesuai dengan instruksi pencarter. Yang dimaksud dengan pelaut adalah nahkoda, perwira, dan anak kapal. ${ }^{7}$

Pengertian "mencarter kapal” itu berbeda dengan "menyewa kapal”. Perbedaan itu terletak pada unsur "pelautnya". Pencarteran kapal adalah penyediaan kapal

\footnotetext{
${ }^{7}$ Purwosutjipto, op. cit., hal. 173.
} 
lengkap dengan pelautnya, sedangkan penyewaan kapal adalah penyediaan kapal itu tanpa pelaut. Jadi dalam hal menyewa kapal, si penyewalah yang mencari pelautnya.

Istilah bare boat charter, yang sering kita dengar dari pengusaha-pengusaha kapal di Indonesia, berasal dari istilah hukum asing, yang dalam hukum Indonesia dapat disamakan dengan istilah "menyewa kapal”. Kalau carter kapal diatur dalam Bab V, Buku II KUHD, tetapi sewa menyewa kapal diatur dalam Bab VII, Buku III KUHPer Di Indonesia sewa kapal itu tidak popular, yang lazim adalah carter kapal. Pemilik kapal, pencarter atau pengusaha kapal merasa lebih aman bila kapal yang dicarterkan dijalankan oleh orang yang sudah dikenal baik dan sudah biasa menangani kapal yang bersangkutan. ${ }^{8}$

Carter Kapal adalah suatu perjanjian timbal balik antara tercarter dengan pencarter, dengan siapa tercarter mengikatkan diri untuk menyediakan kapal lengkap dengan perlengkapan serta pelautnya untuk kepentingan pencarter, dan si pencarter mengikatkan diri untuk membayar uang carter. Carter kapal itu diatur dalam KUHD, Buku Kedua Bab V tentang "Pencarteran Kapal”, mulai Pasal 453 sampai dengan pasal 465 .

\section{Kewajiban Pemilik Kapal dalam Perjanjian Carter Kapal Menurut KUHD}

Dalam perjanjian carter kapal ada dua pihak, yaitu tercarter dan pencarter. Karena perjanjian carter kapal itu adalah perjanjian timbal balik, maka masingmasing pihak mempunyai hak dan kewajibannya. Menurut Pasal 460 KUHD, tercarter atau pemilik kapal mempunyai kewajiban, antara lain:

a. Memelihara kapal dengan sebaik-baiknya sehingga kapal tetap layak laut;

b. Memperlengkapi kapalnya dengan alat perlengkapan yang baik;

c. Memperlengkapi kapalnya dengan pelaut yang cakap, rajin, dan bertanggung jawab;

d. Bila kapal itu digerakkan dengan tenaga mesin, bahan bakar bagi mesin-mesin itu menjadi beban pencarter.

\footnotetext{
${ }^{8}$ Ibid, hal. 174.
} 
Bila hal-hal tersebut tidak dipenuhi dengan baik, dan si pencarter menderita rugi, pencarter dapat menuntut ganti rugi kepada tercarter. Tuntutan ganti rugi itu harus dipenuhi oleh tercarter, kecuali kalau dia dapat membuktikan bahwa dia telah memenuhi kewajiban-kewajiban (Pasal 460 KUHD).

\section{Tanggung Jawab Pemilik Kapal Menurut Carter Waktu}

Di dalam KUHD, Buku II, Bab IV mengatur tentang 2 jenis carter kapal yaitu carter menurut waktu dan carter menurut perjalanan. Dalam pokok pembahasan ini yang akan difokuskan adalah jenis carter kapal menurut waktu. Carter menrut waktu adalah suatu perjalanan dimana si pemilik kapal mengikatkan diri untuk selama satu waktu tertentu, menyediakan sebuah kapal tertentu kepada si pencarter untuk dipergunakannya dalam pelayaran di lautan dengan pembayaran suatu harga yang dihitung menurut lamanya waktu (Pasal 453 alinea ke II KUHD).

Setelah mengetahui tentang jenis-jenis pencarteran kapal, dimana ada 2 (dua) perjanjian yaitu di satu pihak antara pemilik kapal dengan pencarter kapal, yang mempunyai maksud mencarter kapal untuk mengangkut barang-barang miliknya sendiri atau milik orang lain dan dilain pihak antara pencarter sendiri dengan si pemilik barang.

Berbicara tentang pertanggung jawaban pengangkut dalam bab ini, maka akan dibatasi secara khusus pembahasannya pada hal-hal yang berkaitan dengan tanggung jawab para pihak yaitu pemilik kapal dan pecarter kapal untuk angkutan barang melalui laut.

Penyelenggaraan pengangkutan laut, terjadi karena adanya perjanjian yang membawa serta pertanggung jawaban pengangkut. Tentang tanggung jawab pengangkut ini juga diatur dalam KUHD Pasal 468. Dalam Pasal 468 ayat (1) KUHD diatur tentang masa berlakunya tanggung jawab pengangkut yaitu: "Pengangkut diwajibkan untuk menjaga keselamatan barang yang harus diangkutnya mulai saat penerimaan sampai saat penyerahan barang tersebut", maka timbul suatu pertanyaan mengapa demikian dan tidak memberikan suatu kejelasan dimana sebenarnya letak 
memulai tanggung jawabnya, karena kalimat tersebut sangat luas. Bila ditelaah lebih jauh lagi bahwa KUHD Indonesia sejak diberlakukan pada tahun 1936, dimana pada waktu itu keadaan tata niaga dunia dan di Indoneia pengaturannya masih sangat sederhana dan para pengangkut untuk pelaksanaan pekerjaan seluruh kegiatan dipelabuhan menguasai prasarana dan sarananya sendiri, seperti alat transportasi darat, gudang, pelabuhan, dan dermaga, buruh pelabuhan untuk bongkar muat barang, sehingga dalam penerimaan barang dari sipengirim maupun sewaktu penyerahan ditujuan dilakukan melalui tempat yang ditunjuk si penyewa kapal. Sebenarnya KUHD Indonesia menganut asas Konkordansi atau kesamaan dengan Belanda pada waktu itu dimana Indonesia berada dalam kekuasaan pemerintah Belanda.

Selanjutnya Pasal 468 ayat (1) KUHD itu juga berisi kewajiban pengangkut yang menjadi tanggung jawabnya. Selama pengangkut dapat melaksanakan kewajiban itu, maka tidak akan timbul masalah. Timbul masalah bagi pengangkut itu bilamana barang-barang tersebut sebagian atau seluruhnya tidak dapat diserahkan atau menjadi rusak. Ada kemungkinan terjadi bahwa dalam penyelenggaraan pengangkutan terjadi kelambatan dan untuk kelambatan ini perlu diperhatikan Pasal 477 KUHD, yaitu kalau terjadi kelambatan dalam penyerahan barang yang diangkutnya maka pengangkut atau penyewa kapal diwajibkan memberi penggantian kerugian. Namun pengangkut atau penyewa kapal bebas dari tanggung jawab tersebut, bilamana pengangkut atau penyewa kapal dapat membuktikan, bahwa adanya kelambatan itu sebagai akibat adanya peristiwa yang tidak dapat dihindarinya.

Demikian pula dengan KUHD Pasal 468, bahwa pengangkut dapat membebaskan diri dari tanggung jawabnya bila pengangkut atau penyewa kapal dapat membuktikan diri bahwa kerusakan atau kehilangan barang itu bukan akibat dari kesengajaan kelalaian dari pengawasannya atau dari orang-orang yang pengangkut pekerjakan untuk hal-hal tersebut. 
Dalam pokok pembahasan ini yang akan difokuskan adalah Tanggung jawab dari pemilik kapal dan pencarter kapal. Bahwa aturan-aturan dan pertanggung jawaban pengangkut di dalam carter waktu dan carter perjalanan berbeda.

Oleh karena itu akan dibahas dari masing-masing segi atau aspek bagaimana hal tersebut dalam praktiknya sehari-hari.

Didalam suatu perjanjian carter menurut waktu, si pemilik kapal menyerahkan kapal kepada si pencarter artinya si pencarter menyewa kapal tersebut seluruhnya. Dalam mencarter kapal tersebut si pencarter mempunyai kewenangan untuk mengangkut barang-barang miliknya sendiri atau orang lain (Pasal 518 KUHD). Jadi, dalam carter menurut waktu, kapal berada dibawah kekuasaan si pencarter dan bertindak sebagai pengangkut atas angkutan barang-barang yang dipercayakan padanya.

Sebagai pengangkut, si pencarter mempunyai kewajiban untuk bertanggung jawab atas barang yang diangkutnya. Didalam Perjanjian carter menurut waktu si pemilik kapal menyediakan kapal lengkap dengan nahkoda dan anak buah kapalnya. Nahkoda sebagai wakil dari pemilik kapal, tapi meski begitu nahkoda bebas menjalankan tugasnya berada dibawah perintah pencarter karena ia sebagai pelaksana dari pencarter. Tapi keadaan ini tidaklah memutuskan hubungan kerjanya dengan pihak pemilik kapal, karena pemilik kapal adalah pemberi kerja kepada nahkoda, dan antara mereka terdapat suatu perjanjian kerja perburuhan. Walaupun nahkoda harus menuruti perintah pencarter tapi tidaklah seluruhnya diikuti, apabila menurut pikirannya hal yang diperintahkan oleh si pencarter tersebut tidak sesuai (Pasal 518 KUHD).

Dalam hal pertanggung jawaban terhadap keselamatan, pemeliharaan, kehilangan, kerusakan barang, maka hal ini menjadi tanggung jawab dari si pengangkut yaitu si pencarter. Memang tanggung jawab ini tidak sepenuhnya di tanggung oleh pencarter sebagai pengangkut. Pemilik kapal juga bertanggung jawab, 
yaitu berupa suatu kewajiban untuk tetap memelihara keadaan kapal sesuai dengan persyaratan, pada saat dan selama dicarter kapal harus dalam keadaan laik laut.

Didalam suatu perjanjian carter menurut waktu, si pemilik kapal harus menyerahkan kapal dengan disertai kelengkapan awak kapal dan seluruh alat-alat perlengkapan dalam keadaan sempurna guna menunjang perkerjaan bongkar atau muat serta yang paling penting adalah kelaik lautan kapal, yang dalam KUHD syaratsyarat tentang laik laut kapal tidak secara spesifik atau khusus dipertegas dan kurang jelas bagaimana seharusnya dilakukan, meskipun unsur-unsur tersebut ada disebutkan pada pasal-pasal berikutnya meskipun KUHD Indonesia menganut asas kesamaan dari KUHD Belanda pada waktu itu yang belum ada perubahan dan pembaharuan. Tentang kewajiban pengangkut untuk memenuhi persyaratan kapal yang laik laut sebagai syarat utama, dimana pengangkut sebelum dan pada permulaan pelayarannya harus melakukan upaya untuk menyiapkan kapal laik laut dengan:

1) Menyiapkan alat-alat untuk muat bongkar dengan sempurna dan baik;

2) Membuat semua ruangan atau palka, kamar es dan pendingin dan semua bagian kapal yang memuat muatan, fit dan aman untuk penerimaan, pengangkutan serta penjagaannya;

3) Menyediakan cukup bahan makanan;

4) Menyediakan bahan bakar;

5) Menyediakan awak kapal lengkap.

Hal-hal diatas adalah syarat yang mutlak harus dipenuhi untuk dapat melakukan suatu perjanjian di lautan. Jadi apabila ada suatu kejadian barang-barang rusak atau tidak terjaga keselamatannya, dan ketika diteliti ternyata karena akibat dari palka bocor, maka dipastikan bahwa kapal tidak laik laut, dan hal ini jelas merugikan si penyewa kapal, maka pemilik kapal bertanggung jawab tentang hal ini, terkecuali pengangkut dapat membuktikan diri bahwa kejadian tersebut bukan karena kelalaian atau kesalahan si penyewa kapal atau orang-orang yang dipekerjakannya. 


\section{PENUTUP}

\section{A. Kesimpulan}

Berdasarkan hasil penelitian dan pembahasan yang telah dipaparkan oleh Penulis dalam bab terdahulu, maka kesimpulan yang dapat diambil mengenai pertanggungjawaban pemilik kapal adalah perjanjian yang dibuat oleh PT Buana Jaya Pratama dan PT Haluan Segara Line adalah sah dan mengikat secara hukum. Hal itu dikarenakan perjanjian carter kapal yang dibuat oleh PT Buana Jaya Pratama dan PT Haluan Segara Line telah mengikuti prosedur yang ditetapkan undang-undang yaitu Pasal 1320 KUHPer serta isi dari perjanjian carter kapal tersebut tidak bertentangan dengan undang-undang, kesusilaan, dan norma-norma yang hidup di dalam masyarakat Indonesia. Akibat hukum dari adanya perjanjian carter kapal tersebut adalah terjadinya perikatan dalam bentuk carter kapal. Perikatan dalam bentuk carter kapal tersebut berakhir sesuai dengan isi perjanjian pengangkutan yang telah dibuat.

\section{B. Saran}

Dari kesimpulan yang telah ditulis oleh Penulis, maka saran yang dapat Penulis berikan adalah bahwa sebelum melakukan perjanjian jual beli, penyewa kapal harus membaca dengan detail dan teliti isi dari perjanjian tersebut serta mematuhi aturan yang tertuang dalam perjanjian tersebut dan untuk si pemilik kapal tersebut harus menjalani kewajiban yang harus dilakukan dalam perjanjian yang telah disepakati oleh keduabelah pihak

\section{DAFTAR PUSTAKA}

\section{A. Buku}

Baddrulzaman,Mariam Darus. et al. K.U.H. Perdata Buku III: Hukum Perikatan dengan Penjelasan. (Bandung: PT Citra Aditya Bakti, 2001).

Budiono,Herlien. Ajaran Umum Hukum Perjanjian dan Penerapannya di Bidan kenotariatan. (Bandung: PT Citra Aditia Bakti, 2011). 
Cahyono,Akhmad Budi. dan Surini Ahlan, Mengenal Hukum Perdata, Cet. 1, (Jakarta: CV. Gitama Jaya, 2008). Dikutip dari M. Yahya Harahap, Segi-segi Hukum Perjanjian, (Bandung: Penerbit Alumni, 1986).

Harahap,Yahya. Segi-Segi Hukum Perjanjian. (Bandung: Alumni, 1991).

HS,Salim. Hukum Kontrak: Teori dan Teknik Penyusunan Kontrak. (Jakarta: Sinar Grafika, 2006).

Marzuki,Peter Mahmud. Penelitian Hukum. (Jakarta: Kencana Media Group, 2006).

Marzuki,Peter Mahmud. Penelitian Hukum. (Jakarta: Kencana Prenada Media Group, 2009).

Prodjodikoro,R,Wirjono. Azas-Azas Hukum Perjanjian, Cet. 8, (Bandung: CV Mandar Maju, 2000).

Purwosutjipto,HMN. Pengertian Pokok Hukum Dagang Indonesia 5: Hukum Pelayaran Laut dan Perairan Darat. Cetakan ke-4 (Jakarta: Djambatan, 1993).

Santosa,Djohari. Pokok-pokok Hukum Perkapalan, Cet. 2, (Yogyakarta: UII Press Yogyakarta, 2004).

Subekti,R. Hukum Perjanjian. Cetakan kedua. (Jakarta: Pembimbing Masa, 1970).

Subekti,R. Hukum Perjanjian. Cetakan kesembilan. (Jakarta: PT Intermasa, 1984).

Subekti,R. Hukum Perjanjian. Cetakan kesembilanbelas. (Jakarta: PT Intermasa, 2002).

Subekti,R. Hukum Perjanjian. (Jakarta: PT Intermasa, 2005).

Soeroso,R. Perjanjian Di Bawah Tangan. (Jakarta: Sinar Grafika, 2011).

\section{Peraturan Perundang-Undangan}

Indonesia. Kitab Undang-Undang Hukum Dagang. (Jakarta: Pradnya Paramita, 2006).

Indonesia. Kitab Undang-Undang Hukum Perdata. (Jakarta: Pradnya Paramita, 2001). 
Indonesia. Undang-Undang Tentang Pelayaran. UU No. 17 Tahun 2008 LN No.84 Tahun 2008, TLN No. 4849.

\section{Artikel}
Anonim.
"Kepemilikan
Kapal".
www.bppp-
tegal.com/web/index.php/artikel/135-kepemilikan-dan-kebangsaan-kapal

Grace Giovani. "Cara Pendaftaran Kapal di Indonesia”.

http://notarisgracegiovani.com/index.php/2017/07/18/cara-pendaftaran-kapal-diindonesia/, 18 Juli 2017. 